Nasar Meer, Anoop Nayak and Raksha Pande

\title{
The Matter of Race
}

\section{Introduction}

When Barack Obama was first appointed as the US Democratic President in 2008, political commentators heralded his election as a watershed moment in American history. For many he was seen as emblematic of America's changing attitudes to race, and much journalistic ink has subsequently been spilled pontificating about the plight of a 'black man' in the Washington White House. While Obama's achievements have been many they have yet to secure a post-race future and give way to a world where race is finally unbuttoned from the social order. The recent murder in Charleston, USA, of nine people attending the African Emmanuel Methodist Episcopal Church by Dylann Roof, a selfproclaimed advocate of segregation who burned the US flag, adopted the Southern American Confederacy in its place, and has described himself as 'the last Rhodesian', serve only as the latest reminder of the thoroughly interconnected world in which we live and the enduring lineage of race. It is this legacy, and the seeming inability of race to be placed fully under erasure, that we seek to examine through close sociological scrutiny. As the collection of papers in this themed section elucidate - when it comes to the matter of race, race matters.

In approaching these debates Murji and Solomos (2015:9) recently ask, 'What factors explain the mobilising power of ideas about race and ethnicity in the contemporary environment?'. Moreover, 'What counter values and ideas can be developed to undermine the appeal of racist ideas and movements?' (ibid). In this themed section we explore these analytical and political issues directly, but also consider their implications for the sociological tradition from which they emanate. Indeed, while the former focus is an accepted (though perhaps less frequent) site of activity, the latter (namely, the status of race in the sociological tradition) has remained under-explored. The reasons for this are various, and we have elsewhere made clear a set of otherwise opaque historical contingencies between race and the sociological tradition that we think bear continuing relevance today (Meer and Nayak, 2013). This discussion does not need to be repeated here other than to state that there is a compelling and overdue case for emphasizing how and why sociologies of race require 'being attentive to the 
specificities of the current situation but also historical linkages through time' (Les Back, in Meer and Nayak, 2013: 2). One of the implications of this argument, we maintain, is that sociologies of race must go beyond surface level reconstructions, and challenge sociologists to reflect on how their discipline is organised across sociology departments, 'just as sociologists have criticized other disciplines on these matters' (Murji, 2007: 853).

In this respect the interventions here from Sarah Burton, and Les Back and Maggie Tate respectively, are instructive. For Burton, a focus on the figure of the 'white theory boy', or 'dead white male' and his relationship to knowledge production, serves as a means to probe the pedagogy of social theory teaching in the UK. In one classical social theory module, for example, she observes that of the 43 authors listed as 'essential' reading, 37 were white men and 6 were white women, and that 'no authors of colour appeared on the 'essential' reading lists in this course' (Burton, this volume). The trend in her account is generalizable and falls not only along lines of inclusion and exclusion into the 'canon', but in terms of thematic range in as far as minority sociologists are broadly restricted to what are deemed minority topics, rather than the story of sociology more broadly. This inevitably reflects how the 'privileging of white, male, Western, and middle-class identities are ingrained into the very fabric of sociology's ontological foundations' (ibid). The task of 'rediscovering' alternative histories in social theory is therefore ripe and persuasively developed in Back and Tate's contribution, which challenges us to consider what an account of race and the intellectual heralds for the wider sociological tradition. They point in their paper to two overlapping issues. One maintains that the white sociological mainstream has historically ignored the contribution of black sociologists, and the other that the discussion of racism is demoted to a specialist sub-field. Black sociologists by contrast, they argue, have long been attentive to a white sociology that has set the prevailing agenda. Through a detailed exposition of of the writings of W.E.B Du Bois and Stuart Hall in particular, and their respective dialogues with figures like Max Weber and C Wright Mills, Back and Tate make an argument for reconstructing sociology at the levels both of analysis and of form - each of which changes the ways in which sociology can talk about racism. 'What is at stake', they maintain, 'is the possibility of sociological reconstruction that produces an alternative understanding of what sociology can include, starting with augmented modes of telling and writing that attract a broader and more inclusive audience' (Back and Tate, this volume). 
From these two papers which focus on the disciplinary implications of race, this themed sections moves to consider the ways in which race thinking continues to frame public policy issues and discourse. 'Race thinking', Lee reminds us (2015: 27), occurs when ideas about race become the dominant explanatory model for understanding phenomena in the world.' As a consequence, she maintains, 'it may be useful to recast race as a verb, rather than a noun, as in racing or racializing'. This might mean focusing upon the coming-into-being of race and how it is assembled 'through event, encounter and performance' (Nayak, 2011: 549). This succinct summary of a prevailing view helps us to understand how we may invoke racial boundaries without naming race (cf Meer, 2014). While our analysis of this rests on a broadly social constructionist reading, it is also one that understands race as not merely 'behavioural and existential 'scripts", but accepts as foundational that race is 'produced through and by deep social structures' (St Louis, 2015: 130). These structures are not always self-evident and a core objective of this themed section is to remind readers that racial dynamics do not disappear when they are not named, and that it is not difficult to see them distilled in debates about migration and nation, social welfare and austerity, and political extremism and criminal justice. Hence in her contribution Bridget Byrne shows how campaigns around citizenship rights in Britain rely on the production of whiteness in a way that has profound implications for ideas of citizens and non-citizens in Britain, whilst also highlighting the need for a complex range of vocabularies to enable the analysis of different exclusions, not least through intersectional registers. As Lentin (2008) has demonstrated culture, religion, nationality, ethnicity and at times skin colour can perform the work of race. The modernist ascriptions given to 'Europe', 'the West' or the British Isles in a globalized, multicultural context further reveals the fantasies nation states propagate in an attempt to secure the myth of what Ghassan Hage (2000) calls the 'White Nation'. The way in which citizenship is underscored by whiteness can be seen when 'clustered around these imaginations are notions of integration, language and love which rely on shared and interwoven assumptions about race, gender and religion as well as class and sexuality' (Byrne, this volume).

A further objective of the themed section is to remind readers that because of the slippery fashion in which ideas of race have shifted, transmuted and pluralised, race matters can be presented as non-race concerns. In this respect, as Gilroy (2004a: 111) accepted over a decade ago, 'it is impossible to deny that we are living through a profound transformation in the way the idea of 'race' is understood and acted upon'. What we describe might be understood as a trend in recent racial formations, where race 
may go unmentioned but is made emotionally resonant by way of 'resentment as 'a political idea" (Ware, 2008). We find this in the debate about white working class resentment and the ways this is linked to hostility to immigration and multiculturalism, or in the spirited request for migrants to engage in acts of 'community cohesion' from which they are expected to stick together a 'Broken Britain' they are alleged to have fragmented (Nayak, 2012). One frame through which to understand the emotional register of race relates to the relationship between the identity of post-imperial nations and the 'loss of imperial prestige' (Gilroy, 2004b: 98). In Gilroy's terms this postcolonial melancholia 'blinds us to the connections between race-thinking and the white supremacism that legitimized colonial endeavour, so much so that we fail to notice that racism is a problem until the next tragic death or inflammatory eruption shakes us temporarily out of our complacency' (Gilroy, 2006: 5, emphasis in original). This cultural amnesia permits race perpetrators such as Dylann Roof or Anders Behring Breivik to be treated as 'lone wolves' rather than terrorists, individual whites who have little in common with the rest of 'us' being warped, ideologically brain-washed or mentally unstable. In this view collective perceptions of cultural loss 'resurface in the hatred and spite that underlines the deficit of recognition those who carry them feel they are due' (Gadd, 2010). The dis-embedding effects globalization has on locality, housing, the National Health Service or the labour market may enhance these feelings of loss - a reminder that 'nostalgia sits in that space after history ends and biography begins. It is always on the move and invariably personally inflected' (Keith, 2008). As a consequence sections of the white working-class can project themselves as 'victims' with diminishing resources, while immigrants are seen 'as agents of capital rather than fellow objects upon whom capitalist social relations inscribe themselves' (Clarke and Garner, 2010:203).

In this themed section we observe mixed evidence for the nostalgia thesis, and these tendencies are critically explored in the papers by Daniel Burdsey, and Paul Bagguley and Yasmin Hussein respectively, whose contributions span representation and sport, and the ways in which ethnicities encounter crisis, diversity and re-composition in post-imperial settings. Taking up Neal's (2013) account of 'illegible black masculinities', Burdsey focuses on a case study of England cricketer Moeen Ali in order to explore how race, religion and citizenship are configured in the sporting arena and made sense of in the wider popular press and national media. As a Birmingham-born, British Pakistani Muslim playing for England, Ali is only made legible through an ocular grammar of race that marks him out as different (see Back, 2007: 119). This his seen where he is marketed by his local cricketing club Worcestershire and his supporters as 'The Beard That's Feared'; a phrase that at once permits him to be partially 'one of 
us' in terms of his local and national allegiances, but ultimately 'one of them' by dint of his ethnicity, religion and 'Taliban beard' that generates casual associations with imaginary depictions of the stereotypical Islamic terrorist. The implications are that we might 'think differently about the relationship between sport, politics and the sporting hero, and to reconsider conventional analyses of agency, activism and the use of sport as a platform from which to "speak" in the public sphere' (Burdsey, this volume).

In the final paper Bagguley and Hussein present an analysis of how people present and negotiate their ethnicity reflexively in relation to nation, citizenship and processes of racialization. Theoretically they build upon Song's work on ethnic options and ethnic identities but radically problematize and revise this approach to show how reflexivity takes different forms. Using qualitative interview study $(\mathrm{N}=140)$ on how different ethnic groups in West Yorkshire were affected the London bombings on July $7^{\text {th }}, 2005$, they show how these different forms of reflexivity - meta-reflexivity, autonomous reflexivity, communicative reflexivity and fractured reflexivity - become operable amongst different ethnic groups. 'The re-composition of ethnicised identity claims, and increased reflexivity of identity that this is demanding of people', they maintain, 'is seen to be rooted in the political and identity crises generated by Britain's role in and response to the war on terror'. In their analysis these differentiated expressions are rooted in the specific politics and histories of migration and racialization in relation to dominant discourses of whiteness and the state.

Taken together, the themed section widens the aperture to consider the landscape in which such arguments are made, namely in the context of diverging trends in recent sociological scholarship on race. We have mentioned the discussion about nostalgia, but there is a further trend concerning the alleged declining significance of race that is especially reflected in the post-race thesis, and the 'claims that racism [have] finally been transcended and that the "illusion" of race has finally been eliminated' (Winant, 2004: 214). A variety of positions have been informed by this account, and which are entangled in an older argument concerning the nature to which race can be extrinsic to liberal democratic settlements. As St. Louis (2015: 117) puts it:

As an ambition, the post-racial is characterised and haunted by a constituent dilemma. On one hand, as is the current orthodoxy across the life, social and human sciences, race is not real - it does not exist as an empirical object in nature. This epistemological assertion is 
central to the eliminativists rationale. But, on the other hand, race is a powerful normative idea that is believed to be real and, as such, has practical effects and consequences. Therefore, to all intents and purposes, race is real.

This tension sits at the heart of the race debate amongst sociologists, and in recent years we have seen an attempt to critically evaluate race politics and post-race theory (Nayak, 2006) and even to bypass race altogether. Gilroy (2004a: 40-1) of course has made a forceful intervention along these lines:

The only appropriate response to this uncertainty is to demand liberation not from white supremacy alone, however urgently that is required, but from all racializing and raciological thought, from racialized seeing, racialized thinking, and racialized thinking about thinking'. [...] [I]t seems to represent the ethical response to the conspicuous wrongs that raciologies continue to solicit and sanction'

In this themed section we bring together a set of original papers authored by leading scholars who try to explore some of the present and future oriented ways in which race matters. What is interesting is that post-race framings go beyond the significance of race narrowly conceived, and too have been especially influential in reaching across a set of parallel questions concerning how modes of citizenship can reconcile unity and difference. Here we might include those framings that are pro-'diversity' but opposes substantive elements of multiculturalist thought e.g., 'interculturalism', 'superdiversity', and elements of 'cohesion', amongst others (Meer, Modood and Zapata-Barrero, 2015). In Lentin and Titley's (2008: 18) terms, such diversity approaches contain a tendency that 'equalises all differences, and secondly, reduces all inequality to difference'. How do these theoretical critiques take form in empirical research? The papers from Bagguley and Hussain, Burdsey and Byrne, each with different cases and focusing on different scales, take up this question.

A second trend in recent sociological scholarship on race seeks to expand race rather than move past it. Though conceptions of racialization and race-making that are not anchored in Atlantocentric indicators of race, there is an attempt to pluralise racial categories. This is especially the case in debates about Islamophobia and Antisemitism (Meer, 2014), anti-Roma discourse and anxiety towards white European migration (Fox et al., 2012). The facilitating rationale is that race is just one among other concepts in a discipline (sociology) that is 'substantially founded on the notion that all form of sociality 
are constructs, particular relations inscribed in the world from the universe of possible relations' (Smaje 1996: 308).

This argument is not, however, without criticism, and is notably met with the charge that we are witnessing a 'growing culture of racial equivalence' (Song, 2014: 109). In this view 'the concept of racism has suffered from conceptual inflation, resulting in the declining utility of this important concept' (ibid. 108). A recognition of racism's plural character (and its many possible incarnations), therefore, is not unequivocally welcomed but remains necessary if we are to capture the changing status of race concept over a longue durée.

\section{References}

Back, L. (2007) The Art of Listening. Oxford: Berg.

Clarke, S. and Garner, S. (2010) White Identities: A Critical Sociological Approach, London: Pluto Press.

Fox, J. E., Morosanu, L. \& Szilassy, E. (2012) 'The racialisation of the new European migration to the UK', Sociology, $46(4), 680-695$.

Gadd, D. (2010) 'Racial Hatred and Unmourned Loss', Sociological Research Online, 15 (3) 9 <http://www.socresonline.org.uk/15/3/9.html> 10.5153/sro.2208

Gilroy, P. (1990) 'The End of Anti-racism', New Community, 17, 71-83.

Gilroy, P. (2004a) Between Camps. London: Routledge.

Gilroy, P. (2004b) After Empire: Melancholia or Convivial Culture? London: Routledge.

Gilroy, P. (2006) 'Multiculture in times of war', Inaugural address to the LSE, Wednesday $10^{\text {th }}$ May, 2006 <http://www2.Ise.ac.uk/publicEvents/pdf/20060510-PaulGilroy.pdf>

Hage, G. (2000) White Nation: Fantasies of White Supremacy in a Multicultural Society London: Routledge.

Keith, M. (2008) 'Between Being and Becoming? Rights, Responsibilities and the Politics of Multiculture in the New East End', Sociological Research Online, 13(5)11, http://www.socresonline.org.uk/13/5/11.html doi:10.5153/sro.1812

Lentin, A. (2008) 'Europe and the silence about race', European Journal of Social Theory, 11(4): 487-503. 
Soo-Jin Lee, S. (2015) 'Race and the science of difference in the age of genomics', in: Murji, K. and Solomos, J. (2015) (eds) Theories of Race and Ethnicity: Contemporary Debates and Perspectives. Cambridge: CUP.

Meer, N. (2014) (Ed) Racialization and Religion. London: Routledge.

Meer, N. and Nayak, A. (2013) 'Race, Racism and Contemporary Sociology', Sociology, DOI: $10.1177 / 0038038513501943$

Meer, N. and Modood, T., and Zapata-Barrero, R. (2015) Interculturalism and Multiculturalism: Debating the Dividing Lines. Edinburgh: EUP.

Murji, K. and Solomos, J. (2015) Theories of Race and Ethnicity: Contemporary Debates and Perspectives. Cambridge: CUP.

Murji, K. (2007) 'Sociological engagements: institutional racism and beyond', Sociology, 41(5), 843-55.

Nayak, A. (2012) Race, religion and British multiculturalism: the political response of Black and Minority Ethnic voluntary organisations to multicultural cohesion, Political Geography, 31: 454-463.

Nayak, A. (2011) Geography, race and emotions: social and cultural intersections, Social and Cultural Geography, 12(6): 548-562.

Nayak, A. (2006) After race: ethnography, race and post-race theory, Ethnic and Racial Studies, 29(3): 411-430.

Smaje, C. (1997) 'Not just a social construct: theorising race and ethnicity', Sociology, 31 (2), 307-327.

Song, M. (2014) 'Challenging a culture of racial equivalence', British Journal of Sociology, 65 (1), 107-125

St Louis, B. (2015) 'Can race be eradicated? The post-racial problematic', in: Murji, K. and Solomos, J. (2015) Theories of Race and Ethnicity: Contemporary Debates and Perspectives. Cambridge: CUP.

Titley, G. and A. Lentin (2008) 'More Benetton than Barricades? The Politics of Diversity in Europe'. In: G. Titley and A. Lentin (eds.) Politics of Diversity in Europe, Council of Europe Publishing: Strasbourg.

Ware, V. (2008) 'Towards a Sociology of Resentment: A Debate on Class and Whiteness', Sociological Research Online, 13 (5), <http://www.socresonline.org.uk/13/5/g.html> doi:10.5153/sro.1802 